Отримано: 23 серпня 2021 року

Прорецензовано: 6 вересня 2021 року

Прийнято до друку: 20 вересня 2021 року

e-mail: leonoffnatali@ukr/net

virus.net@ukr.net
Leonova N. V., Serdiuchenko Yu. O. Some thematic groups of minor genre forms of information. Syntactic features. Наукові записки Начіонального університету «Острозька академія»: серія «Філологія». Острог : Вид-во НаУОА, 2021. Вип. 11(79). С. 135-139.

DOI: $10.25264 / 2519-2558-2021-11(79)-135-139$

\author{
Nataliia Leonova, \\ PhD of Philological Sciences, \\ Dnipropetrovsk State University of Internal Affairs \\ Yuliia Serdiuchenko, \\ PhD Student, \\ Zaporizhzhia National University
}

\title{
SOME THEMATIC GROUPS OF MINOR GENRE FORMS OF INFORMATION. SYNTACTIC FEATURES
}

The tendency to increase the speed of transmission of relevant information in specific genre information units is growing nowadays. The article attempts to identify and describe the main syntactic features of some thematic groups of minor genre forms of information (hereinafter referred to as MGFI).

It is noted that, acting as only one part of the intonation structure in the sentence, vocative structures of minor genre forms mostly do not require additional disclosure of their content in the context. We single out non-textual existing vocatives belonging to the MGFI of the modern Ukrainian language, which are used in order to attract the attention of an addressee of speech, to encourage them to perceive speech.

Syntactic features of genre forms of information related to the communicative component of the information message: announcements, appeals, prohibitions, information distribution and encouragement to perform an action or a requirement not to perform it in any case. The study deals with the structure and functions of announcements of different types as one of the types of minor genre forms of information, their features as syntactic structures. The structural and morphological features of vocative addresses in minor genre forms of periodical information are also analysed.

Key words: vocative addresses, minor genre forms of information, MGFI syntactic features, non-textual structures, announcements of event presenters, address information, announcement structure, announcement functions.

\author{
Леонова Наталія Валеріївна, \\ кандидат філологічних наук, \\ Дніпропетровський державний університет внутрішніх справ \\ Сердюченко Юлія Олександрівна, \\ аспірантка, \\ Запорізький наиіональний університет
}

\section{ДЕЯКІ ТЕМАТИЧНІ ГРУПИ МАЛИХ ЖАНРОВИХ ФОРМ ІНФОРМАЦЇ̈. СИНТАКСИЧНІ ОСОБЛИВОСТІ}

\begin{abstract}
У наш час посилюється тенденція підвищення швидкості передачі актуальної інформації взагалі і конкретних жанрових інформативних одиниць. Також значно прискорюється інтенсивність обігу та обміну інформацією та ї̈ передачі. У статті зроблено спробу визначити й описати основні синтаксичні особливості деяких тематичних груп малих жанрових форм інформацї (далі в статті-МЖФI).

У дослідженні розглядаються структура й функиії оголошень різних видів як одного з видів малих жанрових форм інформації, їх особливості як синтаксичних побудов. Також аналізуються структурні й морфологічні особливостей звертання-вокативів у малих жанрових форм інформації періодики.

Ключові слова: звертання-вокативи, малі жанрові форми інформачії, синтаксичні особливості МЖФІ, позатекстові конструкиї, оголошення ведучих заходів, інформачійне повідомлення, адресна інформачія, структура оголошень, функції оголошень.
\end{abstract}

Problem statement. Such a complex, multitudinary phenomenon as an address is currently not fully elucidated in modern linguistics. Addresses belong to those language units which constantly attract linguists' attention. As language units, they are parts of a broader category of addressability, which has a communicative nature. The purpose of our article is to analyse the morphological and structural features of addresses in MGFI of periodicals in modern linguistics, taking into account the historical aspect of their development.

Relevance of the study. Linguistically relevant is the analysis of a phenomenon of combining minor genre forms of information (MGFI) in periodicals into a larger number of genre types due to the increase in the number of factors that can be identified as motivating and creative:

- advertising MGFI (advertisements in all types of periodicals);

- purely journalistic MGFI (headlines, lead paragraphs, messages from a host of pblic events, etc.);

- purely informational MGFI (information messages, political calendar, contact information, etc.);

- official MGFI (address of the presiding officer of various social events in transcripts of meetings, plenums, etc.);

- information and journalistic MGFI (greetings, notes on holding actions of different nature with a list of topics discussed, lists of attendees, etc.) [5, p. 243-244]. 
The connection of the author's work with important scientific and practical tasks. This research is related to the topic of a scientific work of the Department of Ukrainian Language of Oles Honchar Dnipropetrovsk National University "Principles of development and functioning of the Ukrainian language", namely, its modern syntactic theory.

Analysis of recent research and publications. The problem of syntactic specificity and the structure of various genre forms of information was studied and analysed by I. O. Annin, Yu. O. Areshnekov, D. Kh. Barannik, L. A. Baturin, A. D. Belov, A. Vezhbytska, O. G. Vetrov, A. A. Volkov, M. N. Volodin, M. D. Gladky, G. P. Gorodylovska, V. I. Grytsyn, T. G. Dobrosklonska, P. S. Dudyk, A. P. Zagnitko, V. V. Zaitseva, G. P. Yevseeva, M. S. Kovalchuk, T. A. Kotz, L. O. Kudryavtseva, S. V. Lazarenko, N. V. Leonova, T. V. Melkumova, G. S. Melnyk, V. Ya. Myronchenko, I. V. Onishchenko, T. G. Serbina, G. Ya. Solganyk, I. O. Talash, R. T. Shulyk and many other famous linguists.

The concept of "morphology" in modern linguistics is interpreted differently. According to one of the most famous concepts, morphology extends to the structure of grammatical units which do not go beyond the word in contrast to the syntax. Some linguists deny the traditional division of grammar into morphology and syntax.

In particular, Ferdinand de Saussure believes that from a linguistic point of view, morphology is devoid of its real object of study and cannot be a discipline other than syntax. There is also a broad definition of morphology, according to which it is a science of forms which relate not only to the means of expressing words in their external manifestation, but also to any elements, including nonverbal means such as word order, intonation, link-words [17]. From this perspective, a number of researchers propose to distinguish between syntactic and analytical (inflectional, non-inflectional) morphology. Thus, the concept of "morphological features" also acquires a dialectical content [9].

The scientific novelty of the article is that for the first time an attempt is made to analyse the syntactic features of minor genre forms of information of different types in applied linguistics on the basis of empirical experience and objectively used in modern philological content collected by the authors.

Main part.

\section{Communicative functions, syntactic features and morphology of addresses in media texts and MGFI}

The main communicative functions of addresses are the function of contact realization and characterization. In modern syntax, the definition recorded in the Linguistic Encyclopedic Dictionary has the most supporters among linguists (1990): "An address is a grammatically independent and intonationally separated component of a sentence or a more complex syntactic consistency, meaning a person or an object to which the speech is addressed". It is necessary to highlight a point of view on the syntactic status of an address, which is considered to be traditional among the generally accepted views in linguistics: "an address" is a separate element in the sentence, to which it is integrated and, accordingly, is not connected by any links with the whole sentence or its parts. This opinion was formulated by O. M. Peshkovsky, who attributed addresses to the elements "which are internally separated in the sentence which gave them a shelter, like a bullet that hit the body" [6, p. 404].

Researchers have differently identified the syntactic status of sentences with addresses. A well-known linguist, V. P. Pronichev, gave a substantiated definition to the syntactic nature of addresses in his monographic study "Синтаксис звертання". Не defines the grammatical features of sentences with addresses, and emphasizes that the presence of all necessary features of an independent syntactic structure in addresses, namely such categories as articulateness, predicativity, mononuclearity, modality, tense, person and number, allows us to consider this syntactic structure along with similar syntactic units which have a similar set of grammatical categories - among mononuclear sentences [8, p. 70].

A common feature of their positions was the syntactic feature of nuclearity, which makes it possible to distinguish addresses to a separate autonomous syntactic unit. O. G. Vetrova notes that according to its syntactic structure: "An appeal is a mononuclear sentence, extended or unextended one, the nuclear component of which can be represented by a noun, adjective or personal pronoun. The common syntactic feature of these components, which are different in their morphological expression, is the syntactic feature of nuclearity" [6, p. 36].

Other linguists, such as Charles Bally, point out that it was once a sentence: "An address was originally an "independent onemember sentence"; a vocative "was not one of the declensions, because once, it was a special integral sentence". On the other hand, some researchers deny the idea that an address can form a sentence: "As for the capability to form a sentence, it is not independent enough. The imperative meaning does not give place to the existential meaning, which could only give the nominative case the meaning of a separate thought" [6, p. 408].

Among the syntactic structures that belong to the information style and are based on oral monologue speech, minor genre forms of information shall be singled out [3, p. 7]. They point to some structural features of oral monologue speech, in particular the use of inserted, exactly inserted, rather than expletive sentences. Researchers believe that during oral communication, the speaker needs to make additional remarks when pronouncing the [6, p. 170].

Methodological or general scientific significance. A group of genre forms of special purpose with a specific stylistic definiteness, which have pronounced syntactic and stylistic features (extra-textual nature, a certain number of stable syntactic structures, etc.), is actively functioning in modern linguistics. These forms are often used in modern oral language practice and, by the genre of the designed materials, belong to the information style of a language [1, p. 5].

The dynamics of mass communication (both oral and written) is so active that prolonged, gradual genre shifts take place in it, whose non-spontaneity is due to such a feature of any literary language as stability. But, these pseudo-paradoxical shifts deprive to some extent the genre of information style of the necessary sign of stability. Today, this linguistic trend is characterized by the phenomenon of adding new types of genres with morphological and structural peculiarities to the genre groups. The genre range of some styles (official and business, journalistic) is expanding, so the boundaries of some genres of information style are blurred due to the renewal of traditional forms of thinking about genre forms in general. The need to build a new syntactic theory requires an updated understanding of the genre [5, p. 240-242].

Since the main features of the genre structures being under consideration are specific structural parameters, grammatical sufficiency, semantic completeness, we can also define them as an optimal and self-sufficient combination of interdependent syntactic constituents that form a communicative unit with a certain typical meaning. The following types of minimal constructions are the 
most producive: nouns, exclamations, phrase-sentences. All of them are expressive means and, when used skillfully, they testify to the linguistic skill of a communicator (speaker), distinguishing their individual style [6].

An address is the main means of expressing the appeal of speech, which is performed verbally and non-verbally. Linguistic and non-linguistic means correlate with each other. Addresses, which function in minor genre forms of periodicals, are isolated constructions, logically complete and have a constant proper grammatical (inflectional) form as per their syntactic and morphological features [5, p. 238-240]. The vast majority of addresses are introduced in periodicals in the vocative form (singular-plural, beingnon-being). V.I. Hrytsyna emphasizes that the analysis of the functioning of addresses in journalistic style reveals some factors which determine the choice of their specific forms, and the nature of communication (formal or informal), influencing the choice of genre, determines the peculiarities of the use of addresses. The researcher points out that the form of addresses is also determined by personal and social relations between people. Both expanded and non-expanded addresses are used in MGFI of periodicals. I.I. Slynko says that non-expanded addresses (name of a person addressed) are used in newspaper texts and magazine articles in the literal sense as a means of communicative sentence-statement, aimed at encouraging the interlocutor to listen as well as to focus their attention.

The form of addresses does not differ in the richness of morphological expressiveness in periodicals. The substantivized forms are mostly used. These forms are expressed by the vocative or nominative cases of proper or common nouns, because the main linguistic function of the address is to name the addressee. Substantivized forms of addresses can be divided into anthroponymic (predominant ones are name / patronym) and appellate ones. This phenomenon can be explained by both the linguistic tradition and the official nature of communication. A more personal form of address is sometimes used - only by name.

Meanings that reflect reality are classified as nominative, and meanings aimed at the internal syntactic structure of a language are classified as syntactic in morphology. It is generally accepted that the intramorphological classification of meanings is based on the understanding of morphology as a system consisting of the actual morphology and word-forming morphology. According to the nature of functional morphemes (affixes), this classification includes word-changing (inflectional, actually grammatical, grammemes,) and word-forming (derivational, classificatory) meanings. Thereafter, when analysing the morphological features of appeals, it should be borne in mind that word-changing and word-forming meanings are the basis for dividing morphological features into two interrelated parts - grammatical morphological (word-changing, paradigmatic) and lexical (word-forming) features. Typically, only the word-changing feature, which is based on regular creation of word forms, is included in the actual morphology[9]. Analysing the morphological and structural features of addresses in MGFI of periodicals, we follow a classification which is close to the classification of appellate forms of addresses, represented by several semantic variants, proposed by V.I. Gritsyna:

Anthroponyms (name, surname, nickname, proper names-appellation), for example: Коваль, Вам слово, прому!; Фракиія “Свобода", дотримуйтесь порядку в сесійній залі! [11].

Social and role names of an addressee by type of activity, position, manner, title and generic terms, for example: Прошу, народний депутат Геращенко; Шановний пане Голово, у ваших останніх інтерв 'ю ви неодноразово говорили, що ви позиціонуєте себе як спікер всієї Верховної Ради; Шановні колеги! Шановні народні депутати! [11].

Socially marked names: друзі, побратими, товаримі, товариство, панове депутати, etc., for eхатрlе: Шановні колеги, шановний народе Украйни! Шановні колеги, прошу звернути увагу вашу, головуючого, і всіх журналістів, і всіх колег - знову ми бачили порушення Конституиії і Регламенту [11].

De-semantic names of an addressee, which are expressed by lexical items with blurred semantics due to frequent use in the function of addressing: люди, брати, країно, сестри, хлопиі, світе, for example: Дайте закінчити, люди, ви ж шановні народні обранці!; Колеги, якщо взяти не лише букву, а сам дух иуієї угоди, то чітко зрозуміло, щцо це не так! [11].

Normative and situational names пані, пане, панове, добродіï, for example: Пані та панове депутати, це ж нормальна міжнародна практика...; Панове, засідання і далі йтиме згідно з Регламентом! [11].

Substantivized adjectives or pronouns, used independently and without dependent attributes, are also common for addresses in MGFI of periodicals, for example: Ви тільки не підвищуйте голос: ні фракиійні, ні позафракиійні; Вельмишановні...; Шановні, почитайте Конвенцію ООН проти корупиії (так вона називається), статтю 19-у цієї Конвенції [11].

It should also be mention about definition of addresses made to the audience by a host of public events. Such addresses belong to the genre type of journalistic MGFI and are implemented with both expanded and unexpanded syntactic structures, and function in terms of several aforesaid semantic variants. For example: Серього!; Серього, ти у нас знаний експериментатор; Пані та панове, зустрічайте! (normative and situational name); Ілля, ти знаєи, тобі дуже пасує ия пісня (anthroponym) [10].

Addresses in MGFI of periodicals are divided into monocomponent, two-component and polycomponent ones as per their structure [5]:

Monocomponent addresses which consist of one word, for example: Панове, у мене дитина-інвалід 5-ти років - я ії не залимаю саму, але через кілька хвилин ми були в суді, тому що двоє великих чоловіків у цивільному одязі почали виламувати мені й дитині руки! [13,].

Two-component addresses, for example: Шановні колеги!; Шановні чатери! Якщо ви не знайшли потрібну статтю або матеріал, будь ласка, скористайтеся пошуком, або завітайте до нашого архіву; "Панове журналісти, ие його куля, вона призначалася Анісімову, але за велінням долі застрягла в моніторі, який розташовувався фактично на рівні грудей”, - кажуть джерела, уточнивши при иьому, щьо куля калібру 7,62 [12, 16].

Polycomponent addresses, for example: Доброго дня, дорога редакціє газети “Київ вечірній”!; Шановний Андрію Івановичу, особливого секрету в приготуванні вина з винограду немає. Дорогі вчителі нашого краю! Велика подяка, правозахиснику Дмитре Коваль і депутате Валентине Наливайко; Педагоги, вихователі, викладачі та наставники - люди нелегкої, але такої почесної і важливої професії! Ви будуєте майбутнє України разом із Президентом, - здоров'я, натхнення, творчих успіхів вам, вітання від голови облдержадміністрації і голови обласної ради!; Спасибі вам, представники старшого покоління, учасники війни й бойових дій, діти війни, за те, що відновили наше зруйноване місто! [15].

V.I. Hrytsyna emphasizes that in the language of journalism, addresses are used in expressions where the basic communicative level is various types of two-nuclear, one-nuclear sentences and syntactic formations, which are called "word-sentences". Among 
the latter, the researcher singles out affirmative "Вболіваємо за вас, дівчата, віримо в перемогу, знаємо, шуо наша земля має талант!", [5, 10], and negative ones. This is fully consistent with the functioning of MGFI addresses in periodicals. It is stated in "Сучасна українська літературна мова: Синтаксис"" edited by I.K. Bilodid that: "Negative word-sentences... are capable to enter into various semantic connections with addresses, insert words and phrases, the lexical meaning and intonation of which... give certain emotionality to the category of negation (this is facilitated by the address)". Ні, пане Голово, я до вас звертаюся 3 проханням; Ні,шановна провладна більшість, для України сьогодні найважливіше - це вступ Украӥни на європейський курс, ие європейська інтеграція, це звільнення політичних в'язнів, це надання можливості Юрію Луценко брати участь в українському політичному процесі, ие свобода для Украӥни $[5,11]$.

Addressess in such units are in the postposition to the negative word-sentence "no", in which the disagreement with an opponent is performed. Mostly, such units with addresses are expanded with two-nuclear or one-nuclear sentences, which substantiate, dynamize the negation, motivate it or emphasize some of its features. For example: Ви за це голосували, мої колеги? Колеги, за це чи ні?; Шановні депутати, ще хто по мотивам чи скінчились нарешті? [5, 11].

Exclamation sentences are somewhat less common than narrative and interrogative ones: Шановний пане головуючий, шановні члени парламенту, проявіть державну мудрість, адже бувають рідкі хвилини в цій парламентській залі, коли ми повинні це робити; Шановні народні депутати, я щее раз вас прошу голосувати персонально тільки своєю карткою [5, 11].

\section{Genre units of information of syntactic level and their specificity}

Some linguists believe that an address as a constituent unit of a sentence in journalistic texts serves to name an addressee of the speech and, naming the addressee, in some cases, it can express the subjective and evaluative attitude to it by a communicant.

As per the structure, mono-, two- and polycomponent multi-word addresses are the most frequently used, among which threeword and multi-word addresses prevail, which are expressed by noun and noun-adjective combinations.

Studying structural and morphological features of addresses in MGFI of periodicals, widely used units, which function in advertising addresses of periodicals, should be mentioned. They also belong to minor genre forms of information in the modern Ukrainian language. Formation and structure of an advertisement is determined by a large number of factors, the most important of which are the goals and characteristics of an effect of an advertisement on a consumer.

In relation to linguistics, these levels are implemented mainly through multicomponent addresses, for example: Завтра о шостій вечора на головній площі міста відбудеться конщерт групи “Бумбокс" (cognitive). Якщо ти справжній украйнець, тебе чекає незабутні дві години драйву!!! (affective). Приходьте самі, приводьте друзів, запрошуйте їх на адреналінову хвилю! (suggestive / subconscious) [14]. In terms of structure, complex addresses are the most common. They can be expressed by noun or noun-adjective combinations, etc. Linguistic aspects of advertising discourse and the place of an address in it as a structural unit of MGFI should be analysed, taking into account the peculiarities of the morphology of the Ukrainian literary language. "Long, complicated by inflections Ukrainian lexical units are difficult to stylistically and phonetically accentuate", states O. Yu. Dubenko in “Англо-американська та українська реклама: лінгвістичні і культурні аспекти стилетворення".

Based on the stages of advertising, as well as the goals and characteristics of an advertising effect, the structure of an advertising address includes such elements as slogans, introductory part, information block, background information, echo-phrase. This division is quite preliminary as in various addresses some elements may be missing.

In some cases, an address can end with an echo-phrase, which literally or meaningfully repeats the slogan or the main motive of the address. Its use is especially effective when a large amount of information is transmitted.

Modern linguistics intensively studies new genre units of information of syntactic level, which is due to the activity in the process of formation of new constructions. This also applies to their structure and functional nature. Announcements of different types at railway stations as minor genre forms of information, their structural features and functions are scantily studied in modern syntax. These syntactic structures belong to specialised mass media, so they should be considered as those that function in the media language and have an appropriate structure. The relevance of the study of this issue is due to the lack of comprehensive analysis of announcements at railway stations, their structural and communicatively functional characteristics, the need for theoretical understanding of syntactic features, lack of a single view on the linguistic status of these entities.

Great attention to the structure and functions of advertisements was paid by such outstanding researches as A. Belova, V. Karasyk, O. Moisyenko and others. Announcements at railway stations by all indications belong to advertising texts.

Linguists state that information texts provide the most adequate material for linguistic research, as most of them are already recorded on various medias, such as radio and video materials. Therefore, we have the opportunity to qualify the language of mass communication as the basic environment of the mass media language.

The article will consider the structure and functions of various announcements at railway stations as one of the types of minor genre forms of information, their specificity as syntactic constructions. The dependence of the structure type on the type of announcement from the standpoint of modern syntax will also be analysed.

Nowadays, there are several types of railway announcements in the information space. The analysis of these constructions shall be based on the statement that: "Announcements are short text messages that contain information for different purposes. Mostly announcements contain private advertising information. They also include information about certain goods or services provided by private individuals or small private enterprises".

Systematization in terms of functional and genre affiliation is mandatory for their typological description as one of the MGFI. The systematization of media broadcasting genres has always been quite complex, which is due to the breadth of the definition of the genre. It is defined as a kind of works of any art that has certain plot and stylistic features; a painting of any subject; a picture of a household plot. Furthermore, it is also a way of doing something in a certain way, a set of style-forming features, an individual author's manner.

Today, the genre is determined by the features that have stabilized and in its entirety is presented as a characteristic of the depicted object, a specific purpose or task. Genre forms of information and advertisements in modern Ukrainian media are systematic, organised, definite forms of a certain structure at a macro level. For a long time, the language of mass communication was studied 
mainly based on lexical material, touching only a little some problems of syntax. So far, there has been no in-depth systematic study, which gives a complete analysis of the language of information in terms of its internal functional and stylistic differentiation and syntactic features [5].

Different types of announcements at railway stations have both commercial purposes (and therefore are widely used on the Internet, on virtual bulletin boards as well as in print media) and non-commercial (informational only). An announcement is an information document that provides information addressed to a specific group of interested individuals (target audience). Announcements are placed on the pages of newspapers, magazines and individual posters, through a loudspeaker and TV / monitor screens. According to their content, announcements are divided into two types: 1) announcement of any event; 2) announcement aimed at providing some information or other services.

The structure of announcements at railway stations is a scantily studied issue as these syntactic structures have not been the subject of systematic linguistic analysis yet. H. Glushko emphasizes that there are different types of text announcements as models (within cognitive psychology) which have both normative and optional elements, which are supplemented individually. The researcher notes that the prototype structure of announcements assumes the presence of content and thematic aspects in the centre of attention of communicators. Therefore, we can say that the author of the text when formulating the announcement should follow the typical style of the announcement text.

Conclusions. In due course time, when a certain type of announcement becomes familiar, the number of elements may decrease, as the target audience, to which the information or advertising message is directed, already knows the mentioned constructions. A mandatory basic structure for MGFI may be extended by numerous optional elements, which in some cases are part of mandatory ones or partially intersect with them. For example, announcements at railway stations are often started with an explicit call, which intensifies the function of establishing contact.

Addressing a recipient is an appealing conclusion to the announcement and aims to finally narrow the audience to the only relevant person who knows the context and can understand the content of an announcement. By means of the above scheme of elements, it becomes possible to structure and analyse most of the announcements at railway stations, and the sequence of individual structural elements is arbitrary. They can separate from each other, intensify each other, and supplement each other. Based on empirical analysis, it was found that the number and sequence of optional elements of the basic structure differs depending on the type of announcements and their syntactic features.

Summary. The relevance of the study of such syntactic units as addresses in MGFI and announcements at railway stations is due to the need to develop and deepen a new syntactic theory, not limited to the analysis of the syntax of genres and genre forms as parts of the textual plane. The existence of self-sufficient structures, the syntax of which depends on the intonation of the subjects of speech, for example, of hosts of mass events (concerts, meetings, conferences, etc.) or advertising addresses in periodicals, is also studied, as well as the features of formation and functioning of syntactic structures in oral speech.

The investigation of these units actualizes the study of language development processes which are inherent in the very syntactic structure of the Ukrainian language and begin in a simple one-nuclear sentence, gradually extending its influence to the complex one.

Prospects for the use of research results. The study of the syntax specifics of minor genre forms of information by analysing their morphological and structural features and their functioning as genre forms of special purpose, with specific syntactic certainty, has a very objective practical significance, which is that the results can be used in systemic linguistic research of various genre forms of information within separate functional styles of a language, for further research of the genre system of language and genre forms of oral and written speech. They can also be used in lectures and practical classes on the syntax of the modern Ukrainian language, stylistics. The results of the research can be used empirically in the practical activities of specialists in the information sphere, distance learning, etc.

References:

1. Баранник Д. Х. Актуальні проблеми дослідження мови масової інформації. Мовознавство. 1983. №8. С. $13-17$.

2. Вихованець I.P. Морфологія. Українська мова: енциклопедія. Київ: Українська енциклопедія, 2000. 752 с.

3. Ветрова О. Г. К проблеме обращения в современном английском языке. Лингвистические исследования - 1979: Синтаксический анализ разносистемных языков. Москва : АН СССР, 1979. С. 30-37.

4. Грицина В. І. Інфраструктура речень публіцистичного стилю : автореф. дис... канд. філол. наук: 10.02.01. Запоріжжя, 2002. $19 \mathrm{c}$.

5. Леонова Н. В. Морфологічні та структурні особливості звертання в МЖФІ періодики (на матеріалі запорізьких періодичних видань). Вісник Запорізького національного університету: зб. наук. прачь. 2013. Вип. 3. С. 238-245.

6. Пєшковский А. Русский синтаксис в научном освещении. Москва: Учпедгиз, 1956. 511 с.

7. Проничев В. П. Обращение и понятие. Вестник ЛГУ. 1968. №20. 120 с.

8. Проничев В. П. Синтаксис обращения. Ленинград : Изд-во Ленингр. ун-та, 1971. 88 с.

9. Морфологія (мовознавство). URL: uk.wikipedia.org/wiki (дата звернення: 10.07.2021).

10. Стенограми засідань Верховної Ради. 2017. Липень. URL: rada.gov.ua/meeting/stenogr/show/4128.html (дата звернення: 05.08.2021).

11. Запорізька правда. 2010. Bересень. URL: zp-pravda.info/index.php?option = com_content\&view = article\& $\mathrm{id}=2070: 2010-09-23-20-14-05 \&$ catid =42:2009-05-25-14-52-08\&Itemid=63 (дата звернення: 05.08.2021)

12. Запорізька правда. 2010. Вересень. Режим доступу: zp-pravda.info/index.php?option $=$ com_content\&view $=$ article\& $\mathrm{id}=2070: 2010-09-23-20-14-05 \&$ catid $=42: 2009-05-25-14-52-08 \&$ Itemid $=63$.

12. Правда. 2013. Липень. URL: pravda.com.ua/news/2013/07/12/6994122 (дата звернення: 06.08.2021).

13. Запорізька правда. 2009. Квітень. URL: zp-pravda.info / index.php?option = com_content\&view =article\&id =45:2009-04-14-11-10-21\&catid =1:latest-news (дата звернення: 17.07.2021).

14. Запорізька правда. 2013. Липень. URL: zp-pravda.com.ua / columns /2013/ 07/30/387486/http: // zp-pravda.info / index.php?option $=$ com_content\&view $=$ article\&id $=2070: 2010-09-23-20-14-05 \&$ catid $=42: 2009-05-25-14-52-08 \&$ Itemid $=60$.

15. Правда. 2013. Серпень. URL: pravda.com.ua/news/2013/08/17/6996220 (дата звернення: 25.07.2021).

16. Соссюр Ф. де. Заметки по общей лингвистике. Пер. с фр. Б. П. Нарумова. Москва : Прогресс, 1990. 44 с.

17. Сучасна українська літературна мова: Синтаксис / під ред. І. К. Білодіда. Київ : Наук. Думка, 1972. 516 с. 